\title{
The case of primary endobronchial neurinoma
}

\author{
Hisako Kushima, ${ }^{1}$ Hiroshi Ishii, ${ }^{2}$ Fumito Okada, ${ }^{3}$ Jun-ichi Kadota ${ }^{4}$
}

${ }^{1}$ Department of Respiratory Medicine, Oita University Hospital, Yufu, Japan 2Department of Respiratory Medicine, Fukuoka University Hospital, Fukuoka, Japan ${ }^{3}$ Department of Radiology, Oita University Hospital, Yufu, Japan

${ }^{4}$ Department of Respiratory Medicine, Oita University Hospital, Yufu, Japan

\section{Correspondence to} Dr Hisako Kushima, hkushi@oita-u.ac.jp

Accepted 2 November 2014

\section{DESCRIPTION}

A 71-year-old woman was referred due to chest discomfort. She had normal breath sounds with normal pulmonary functions. A chest roentgenogram was also normal, while a transverse thin section CT image (1 mm section thickness) showed bronchial wall thickening with calcifications in the left lower bronchus (arrows, figure 1). A reconstructed coronal CT image in the lung window showed focal narrowing of the left lower bronchus (arrows, figure 2). Bronchoscopy revealed diffuse redness and thickening of the bronchial mucosa with mild stenosis of the left lower bronchus (figure 3). The pathological diagnosis of a transbronchial biopsy was neurinoma composed of spindle cells with a palisading pattern (figure 4) containing S-100 protein-positive cells (inset), which was distinguishable from leiomyoma or meningioma by the absence of abundant elongated eosinophilic cytoplasm or inflammatory infiltration of plasma cells. The patient had neither acoustic neurinoma nor cafe-au-lait spots on the skin. She is considered to be at risk of bronchial stenosis in the future, and it may be necessary to consider bronchoscopic argon plasma coagulation ${ }^{1}$ or left lower sleeve lobectomy. However, the CT findings have remained stable for 10 years, and watchful observation has proven to be a valid choice in this case. Primary endobronchial neurinomas are extremely uncommon, constituting approximately $2 \%$ of benign tracheobronchial tumours. ${ }^{2}$ Surgery

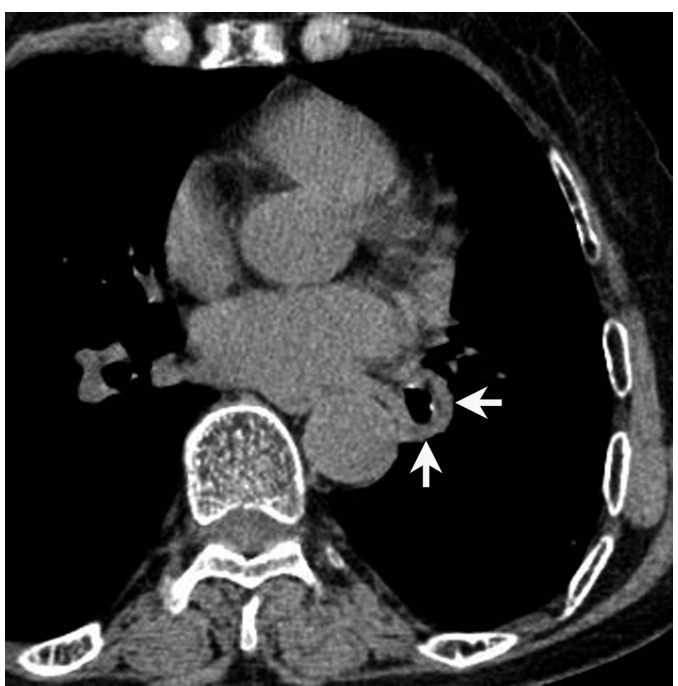

Figure 1 A transverse thin section CT image (1 mm section thickness) showing bronchial wall thickening of the left lower bronchus (arrows).

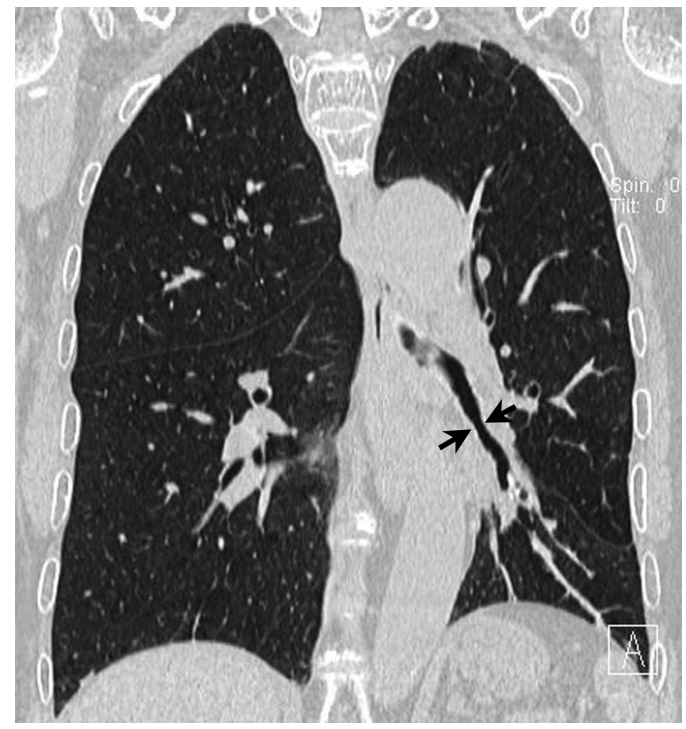

Figure 2 A reconstructed coronal CT image in the lung window showing the focal narrowing of the left lower bronchus (arrows).

had been chosen in most reported cases of endobronchial neurinoma ${ }^{1}{ }^{3}$; however, an awareness of the possibility of this disease and proper management based on each patient's clinical condition is required. We presented a rare case of primary endobronchial neurinoma with fascinating imaging findings. ${ }^{3}$

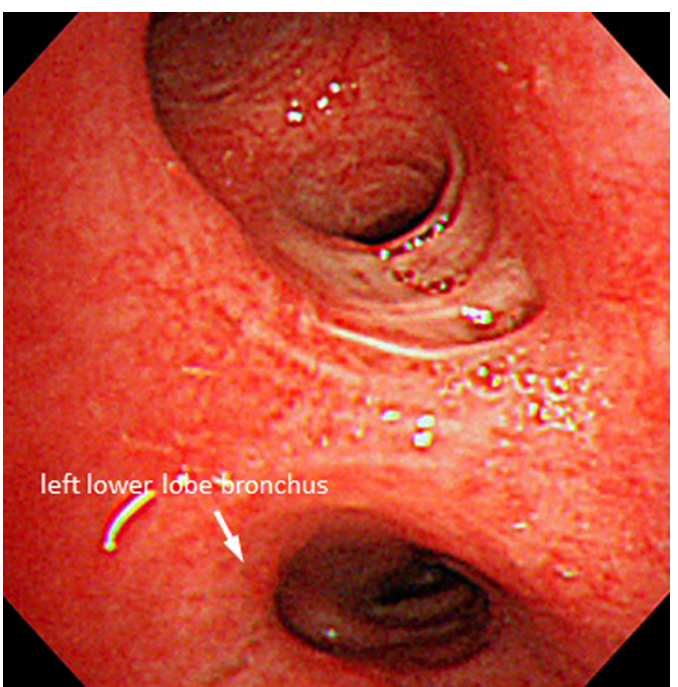

Figure 3 A bronchoscopy image showing diffuse redness and thickening of the bronchial mucosa with mild stenosis of the left lower bronchus. 


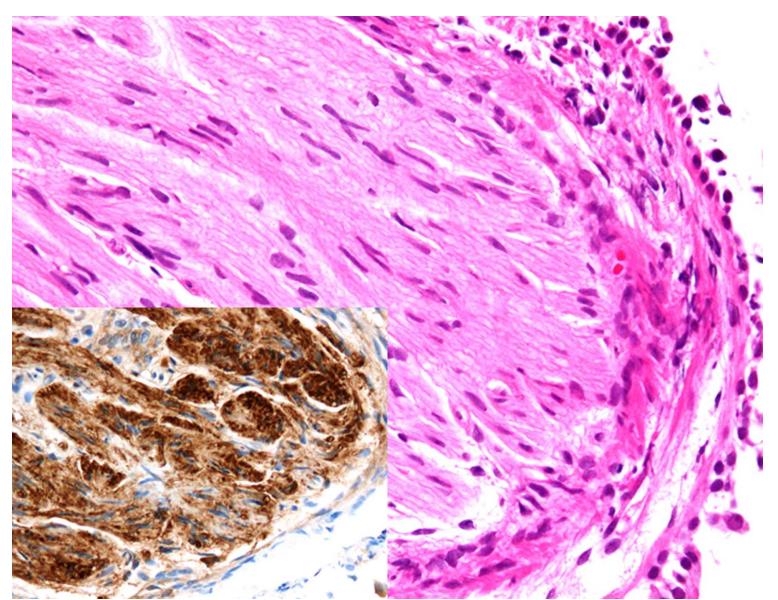

Figure 4 A transbronchial biopsy showing neurinoma composed of spindle cells with a palisading pattern (H\&E staining, $\times 400)$ containing S-100 protein-positive cells (inset).

Contributors HK is the doctor in charge of the patient, and wrote the first draft of the manuscript. HK and $\mathrm{HI}$ performed a transbronchial lung biopsy and rewrote new drafts based on comments from co-authors. FO provided radiological confirmation and constructed figures. All authors provided clinical, radiological and pathological confirmation of primary endobronchial neurinoma, and approved the final manuscript.

\section{Learning points}

- Primary endobronchial neurinoma is one of uncommon benign tracheobronchial tumours.

- A reconstructed coronal $\mathrm{CT}$ image in the lung window is impressive for this disease.

- The pathological diagnosis is necessary for distinguishing from other tumours, such as leiomyoma or meningioma.

\section{Competing interests None.}

Patient consent Obtained.

Provenance and peer review Not commissioned; externally peer reviewed.

\section{REFERENCES}

1 Lee BR, Choi YD, Kim YI, et al. Endobronchial schwannoma treated by rigid bronchoscopy with argon plasma coagulation. Tuberc Respir Dis (Seoul) 2012;73:174-7.

2 Shah H, Garbe L, Nussbaum E, et al. Benign tumors of the tracheobronchial tree. Endoscopic characteristics and role of laser resection. Chest 1995;107:1744-51.

3 Kasahara K, Fukuoka K, Konishi M, et al. Two cases of endobronchial neurilemmoma and review of the literature in Japan. Intern Med 2003;42:1215-18.

Copyright 2014 BMJ Publishing Group. All rights reserved. For permission to reuse any of this content visit http://group.bmj.com/group/rights-licensing/permissions.

BMJ Case Report Fellows may re-use this article for personal use and teaching without any further permission.

Become a Fellow of BMJ Case Reports today and you can:

- Submit as many cases as you like

- Enjoy fast sympathetic peer review and rapid publication of accepted articles

- Access all the published articles

- Re-use any of the published material for personal use and teaching without further permission

For information on Institutional Fellowships contact consortiasales@bmjgroup.com

Visit casereports.bmj.com for more articles like this and to become a Fellow 